\title{
New Components in the Volatile Oil of Sage
}

\author{
HADI A. AL-NAJJAR, Ph.D. \\ The Department of Pharmacy, College of Health Sciences, Public Authority for Applied Education and Training (PAAET), \\ Kuwait
}

\begin{abstract}
Background: The volatile oil of dried leaves of "Sage" Salvia Officinalis was obtained by hydrodistillation $(1.2 \%$ $\mathrm{v} / \mathrm{w})$.

Aim of Study: This study was designed to analyze the volatile oil by (GC-MS).

Material and Methods: Crushed dried Leaves (100g), were subjected to hydrodistillation E.P. (1984) GC-MS analysis was performed on Hewlett Packard 5850 GC connected to an HP 5970 quadruple nano spectrometer (70cw) and an HP 9000 work station with helium as the carrier gas.

Results: 26 components representing $95 \%$ of the total oil were identified. Four of these components Linolool, Borneol, a-Terpinol and Thujone were most abundant constituents of the oil about $(51 \%)$. In addition significant amounts of unreported constituents were found to be present such as peaks No. 12, 16, 17, 18 whose Mwt and preliminary chemical structure were suggested and called Kuwaitene 1,2,3,4 by author.

Conclusion: GC-MS analysis of the volatile oil revealed at least 35 components, most of which could be identified, 4 of which were not reported in the literature before and reported here for the first time. (Peak No 12, 16, 17, 18 whose M. wts: 136 (1,4-Cyclohexanone, 1-Methyl 4, J-Methylethyl) 152 (Chrysanthone), 154 (3-Cyclohexen, 4-Methyl (I-Methyelthyl), 154 (Isomer) respectively).
\end{abstract}

Key Words: Sage - Salvia officinalis leaves - Volatile oil GCMS-Kuwaitene 1, 2,3,4.

\section{Introduction}

SAGE Officially Known as Salvia Officinalis L. The name sage comes from the latin "Salvere" or salvation meaning "to be in good health, to cure or to save". Sage was a sacred ceremonial herb of the Romans. It was associated with immortality, and was thought to increase mental capacity. The Chinese valued the use of in teas, and the American Indians used it for medicinal purposes. In Kuwait,

Correspondence to: Dr. Hadi A. Al-Najjar, The Department of Pharmacy, College of Health Sciences, Public Authority for Applied Education and Training (PAAET), Kuwait it is used as a stringent, to improve digestion, blood circulation in debility and convalescence. It is used to reduce night sweats, treatment of excessive salivation, as a gargle against throat and mouth infections [1-4].

In a study on the essential oil of the common sage. It was found to contain about $23.7 \%$ of $\alpha$ thujone and $\beta$-thujone which were responsible for the characteristic odor and flavor [5].

Pitarevic \& Raic et al., reported that the yield and composition of essential oil changed from month to month and the maximum in essential oil in the leaves appeared during July. Correlations between geographic origin and composition indicated that the quantity and composition could vary with regard to the main component $\alpha$-thujone, $\beta$ thujone, camphor and cineole [6,7].

In another study by Pascaglia, et al., it was found that constituents, $\beta$-thujone, camphor, $\mathrm{P}$ Cymene, $\beta$ caryophylene, $\alpha$-humulene and cargophylene oxide of Salvia Officinalis oil were effected significantly by various concentrations of fertilizers [8]

Tekelova and Felkolva reported in a different study that contents of essential oil, hydroxycinamic and derivatives in separate leaf insertions were found to be highest in middle part of the herb and top of the herb respectively [9] .

Gomez et al., reported that other components, such as 1,8 -Cineole $(15.71 \%)$, manool $(1.94 \%)$

\footnotetext{
Abbreviations:

PAAET : Public Authority for Applied Education and Training.

GC-MS : Gas chromatography-mass spectrometry.

IR : Infrared.

Mwt : Molecular weight.

EO : Essential oil.
} 
and viridiflorol were found in the essential oil of salvia officinalis using GC, IR and GC/MS techniques [10].

The hypoglycenic effect of volatile oils of sage and other plants were reported by Essaway et al., [11] to be significant in rats at 1 and 3 hours. In the same study the LD 50 was found to be $1950 \mathrm{mg} / \mathrm{kg}$.

The effects of Salvia Officinalis essential oils main constituents were studied by Carta et al., on Bocrytis Ginerea fungus and compared with the action of two synthetic plant fungicides prodione and benomyl and it was found that in the essential oil, its oxygenated fraction and the camphor showed fungicidal activity in dosses of 2.2, 1.85 and $1.75 \mathrm{~g} / \mathrm{L}$ respectively. While 1,8 -Cineole had no significant effects on the test organism [12]

Karawya et al., reported the presence of Campor and thujone in levels reaching up to $45.7 \%$ of the total make up of the essential oil of S. Officinalis [13].

Further studies on other species such as S. glutinosa L, growing in southern Italy and S. aurea $\mathrm{L}$ and other wild species grown in spain showed similar constituents [14-17].

\section{Material and Methods}

Experimental:

Plant material:

The dried leaves were imported from Hamdard laboratories, Haider Ahad, Pakistan who provide most of the plant materials used at the Islamic medicine Centre here in Kuwait with authenticated documents.

\section{Oil preparation and analysis:}

Crushed dried Leaves (100g), were subjected to hydrodistillation E.P. (1984). The composition of the volatile constituents was established by GCMS analyses on Hewlett Packard 5850 GC CONNECTED TO AN HP 5970 quadruple nano spectrometer $(70 \mathrm{cw})$ and an HP 9000 work station with helium as the carrier gas.

J \& W Scientific operated in split mode 50: 1 Conditions; Inhector Temp, $285^{\circ}$, deccript temp, $295^{\circ}$, initial Oven temp, $80^{\circ}$ held for $1 \mathrm{~min}$, increased $80^{\circ} / \mathrm{min}$ to $145^{\circ}$ and held for $6 \mathrm{sec}$. Then increased $50^{\circ} / \mathrm{min}$ to $275^{\circ}$ and held for $5 \mathrm{~min}$. Qualitative identification of the components was achieved by the automated data bank library attached to the GCMS and the data obtained are listed in (Tables 1,2).

Table (1): Identified components of the volatile oil of salvia officinalis (reported).

\begin{tabular}{|c|c|c|c|c|}
\hline Peak No. & R.Time & M.Wt & Chemical Name & Structure \\
\hline 1 & $7.272-7.314$ & 136 & $\begin{array}{l}\text { 1,3,6 Octatriene } \\
\text { 3,7-dimethyl }\end{array}$ & \\
\hline 2 & $7.725-7.767$ & 136 & Camphene & \\
\hline 3 & $8.667-8.708$ & 136 & Beta-pinene & \\
\hline 4 & $9.292-9.33$ & 136 & Beta-myrcene & \\
\hline 5 & 10.133 & 136 & 1,3-Cychlohexadiene & \\
\hline 6 & $10.383-10.450$ & 134 & $\begin{array}{l}\text { Benzene 1-methyl } \\
\text { 4-methylethyl }\end{array}$ & \\
\hline 7 & $10.625-10.700$ & 154 & Eycalyptol & \\
\hline
\end{tabular}


Table (1): Cont.

\begin{tabular}{|c|c|c|c|c|}
\hline Peak No. & R.Time & M.Wt & Chemical Name & Structure \\
\hline 9 & $12.742-12.775$ & 136 & Terpincilen & \\
\hline 10 & $13.217-13.250$ & 154 & Linollool & \\
\hline 11 & $13.308-13.350$ & 152 & Thujone & \\
\hline 13 & $14.675-14.742$ & 152 & Camphor & \\
\hline 14 & $15.367-15.408$ & 172 & $\begin{array}{l}\text { Bornyl chloride or } \\
\text { turpentine camphor }\end{array}$ & \\
\hline 15 & $15.517-15.67$ & 154 & $\begin{array}{l}\text { Borneol } \\
1-2 \text { camphanol }\end{array}$ & \\
\hline 18 & $16.449-16.525$ & 154 & Alpha-terpineol & \\
\hline 21 & 20.208 & 150 & $\begin{array}{l}\text { Phenol, 2-methyl-5 } \\
\text { (I-methylethyl) }\end{array}$ & \\
\hline 24 & $24.475-24.533$ & 204 & Isocaryophyliene & \\
\hline 25 & $25.113-25.158$ & 204 & Caryophyllene & \\
\hline 34 & 29.939-29.982 & 222 & Ledol & \\
\hline
\end{tabular}


Table (2): Unidentified components of the volatile oil of salvia officinalis (unreported).

\begin{tabular}{|c|c|c|c|c|}
\hline Peak No. & R.Time & M.Wt & Chemical Name & Structure \\
\hline 8 & 11.683 & 136 & $\begin{array}{l}\text { 1,4-Cyclohexanone } \\
\text { 1-Methyl } 4 \\
\text { (J-Methylethyl) } \\
\text { (Kuwaitene 1) }\end{array}$ & \\
\hline 12 & $13.717-13.758$ & 152 & $\begin{array}{l}\text { Chrysanthone } \\
\text { (Kuwaitene 2) }\end{array}$ & \\
\hline 16 & 15.608 & 154 & $\begin{array}{l}\text { 3-Cyclohexen } \\
\text { 4-Methyl (I-Methyelthyl) } \\
\text { (Kuwaitene 3) }\end{array}$ & \\
\hline 17 & $15.958-16.00$ & 154 & $\begin{array}{l}\text { Isomer of } 16 \text { (above) } \\
\text { (Kuwaitene } 4 \text { ) }\end{array}$ & \\
\hline
\end{tabular}

\section{Results}

The leaves of Salvia Officinalis afforded on hydrodistillation a pale yellow volatile oil (Yield in $25 \% \mathrm{v} / \mathrm{w}$ ). It has a characteristic sage like odour and is soluble in chlorofoam, benzene, ether and alcohol.

GC-MS analysis of the volatile oil (Table 1) revealed at least 35 components, most of which could be identified, 4 of which were not reported in the literature before (Peak No 8, 12, 16, 17, M.wts: 136 (1,4-Cyclohexanone, 1-Methyl 4, JMethylethyl) 152 (Chrysanthone), 154 (3Cyclohexen, 4-Methyl (I-Methyelthyl), 154 (Isomer) respectively). The Chemical names and library matches are listed in Table (2).

\section{Discussion}

Salvia officinalis L. and Salvia sclarea L. have an important place in world trade as they have important economic value for the perfume and cosmetic industry [18].

The medical sage (Salvia officinalis L.) has extensive uses. It is widely used in medicine, food, drink, perfume and cosmetic industries [19,20]

Germacrene-D (32.9\%), 0 -caryophyllene $(31.8 \%)$ and caryophylleneoxide (23.2\%) were determined in a study as the main components among the 43 compounds identified by GC/MS. analysis of the volatile oil composition of Salvia officinalis L. grown in Cuba [21].

The essential oil (EO) composition of Salvia officinalis L. grown in North India was investigated using gas chromatography (GC/FID) and GC-mass spectrometry (GC/MS). The required oil yield varied between $0.22-0.43 \%$ and $0.15-0.60 \%$, respectively, depending on harvest season and processed plant parts. Sixty components were determined corresponding to $95.5-99.2 \%$ of the fat compositions. Cis-thujone (19.8-42.5\%), (E)caryophyllene (1.2-16.1\%), manool (3.6-15.1\%), viridifluorol (\%3.1-12.8), 1.8-cineole (2.8-13.8\%), camphor (1.4-22.1\%), borneol (0.9-4.8\%), ahumulene (1.5-4.5\%), (3-pinene $(0.7-4.1 \%)$, and trans-thujone (1.4-3.7\%) were the main identified components of the essential oil [22].

Karayel and Akcura, 2019 reported that as athujone, Camphor, 1,8-cineole were the main components of the volatile oil from Medical sage Salvia officinalis L. (hybrid) growing in three different locations [23].

The results of the present study was consistent with the findings of these investigators. 
GC-MS analysis of the volatile oil revealed at least 35 components, most of which could be identified, 4 of which were not reported in the literature before.

The reasons for these differences can be attributed to many different factors such as the variability in volatile oil composition due to the flowering time of the salvia plant, geographic and climatic factors in addition to the variety and amount of bioactive substances found in medicinal and aromatic plants may also vary according to the part of the plant used, post-harvest processes and the way of obtaining the essential oil as well as the analysis methods [24]

\section{Conclusion:}

In Conclusion, four new products were reported by GC-MS analysis of the volatile oil. Further investigation in the nature of these unreported components is recommended. interest.

Conflicts of interest: There are no conflicts of

\section{References}

1- CASTLEMAN M.: Medicinal Plants. Remedies for over 200 disease, p. 503-510. Dar Al-Moualef, Lebanon, Beirut, 1997.

2- MILLS S.: The complete Guide to Modern Herbalism, p.186 Thorsons, London, 1989.

3- ODY P.: Handbook of over the counter herbal medicines. Kyle Cathie limited, London, 1995.

4- BATANONI K.H.: Secrets of Herbal treatments between modern Science and common herbalist. Kuwait institute for Scientific Research, Kuwait, 1994.

5- EMBONG M.B., HAZIYEV D. and MOLINAR S.: Can, Inst. Food Sci. Technol, J. 10 (3): 201-7 (1997); through Chem. Abstr., 87, 430, 1977.

6- PITAREVIC L., KUFTENIC J., BLAZEVIC N. and KUSTRAK D.: J. Nas, Prod, 47 (3): 409-12 (1984) through Chem. Abstr., 101, 362-3, 1984.

7- RAIC D., NOVE R. and FAVCI J.: Eng. 35 (2): 121-5, 1985.

8- PASCAGLIA R., MONANI M., GACENI G. and RASENT J.: Oil Res. Through Chem. Abstr. (III), 1505434, 1999.
9- KELOVA T.E. and ELKLOVA M.F.: Pharmacies, 93940 (Ger) through Chem. Abstr., (320): 562, 1994.

10- GOMEZ P.S., GARCIA M.C. and VALLEJO I.: Essent Oil Res. (1) 117-18 (Eng), through Chem. Abstr., 125.

11-ESSWAY G.S., SOBHY H.M., EL HEZA H.A. and GIZA J.: Chem. Abstr., 43 (2): 167-172 (Eng.), Vol. 125, No. 15, 1996.

12- CARTA C., MORETTI M.D.L., PENTA A.T. and EASENT J.: Oil Res., 8 (4): 399-404 (1996) Eng, via Chem. Abstr., 126, No. 21, 1997.

13- KARAWYA M.S. and EL HAWARY S.S.: Chem. Abstr., Egypt, Sei., 19 (1-4): 301-5 (Eng.) Via, 14, 308, 1981.

14- SENAORE F., DE FQACO R., DEFOE V. and EASENT J.: Oil Res., 9 (2): 151-157 (1997), p. 1092 Via Chem. Abstr., 126, No. 21, 1997.

15- SERRACI-VALENTI G., BITIO A., CONTRA L. and GARALO G.: Ann. Bot. 97 (3): 329-336 (1997), via Chem. Abstr., 126, No. 21, 1997.

16- TORRES M.E., VELASCO A., NEGOTRATIC M.J.A., PINILA M.G. and EASENT J.: Oil RES 9 (1): 17-33 (1997), VIA Chem Abstr., 126, 14: p. 372, 1997.

17- Egyptian Pharmacopocia, General Organization for Governmental Printing Office, Cairo, 1984.

18- LAHLOU M.: Essential oils and fragrance compounds: bioactivity and mechanisms of action. Flavor Fragrance J., 19: 159-165, 2004.

19- DEMIRCI B., PISTOL N. and BASER K.H.C.: Enantiomeric distribution of some of the essential oils of some Salvia Species. Flavour Fragrance J., 17: 54-58, 2002.

20- PESIC Z.P. and BANKOVIC V.M.: Investigation on the essential oil of Salvia sclarea L. Flavour and Fragrance Journal, 18: 228-230, 2003.

21- PINO J.A., AGUERO J. and FUENTES V.: Essential oil of Salvia officinalis L. ssp. altissima grown in Cuba. J. Essent. Oil Res., 14: 373-374, 2002.

22- VERMA R.S., PADALIA R.C. and CHAUHAN A.: Harvesting season and plant part dependent varieties of Salvia officinalis L. grown in northern India. J. Herbal Med., 5: 165-171, 2015.

23- KARAYEL H.B. and AKÇURA M.: Examination of the changes in components of the volatile oil from Abyssinian sage, Musk sage and Medical sage growing in different locations. Grasas Aceites, 70 (3), 2019.

24- RAJABI Z., EBRAHIMI M., FARAJPOUR M., MIRZA M. and RAMSHINI H.: Compositions and yield variation of essential oils among and within nine salvia species from various areas of Iran. Indus. Crops Prod., 61: 233239,2014 


\section{المكونات الجديلة فى الزيت المتطاير من المرامية}

$$
\text { الهدف من الدراسة: تحليل الزيت المتطاير من المرامية. }
$$

خطة البحت: فى هذه الدراسة تم الحصول على الزيت المتطاير للأفداق المجففة من المرامية عن طريق التكسير المائى ثم تعرضت

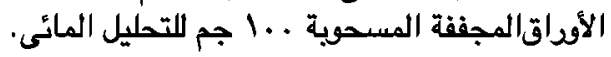

نتائج البحث: بمقارنة نتائج البحث بالنسبة النتائج التى تم الحصول عليها فى الأبحاث السابقة، وجدت النتائج كالآتى: تحديد דr مكن معروف من قبل تمثل 90\% من إجمالى الزيت. وأخيراً هذه الدراسة تؤكد أنه تم اكتشاف أربعة مكونات جليدة لم يتم ذكرها من قبل فى الأبحاث السابقة. 